\title{
Transport support for the processes of globalization in Russia
}

\author{
Viktor Podsorin ${ }^{1, *}$, and Elena Ovsiannikova ${ }^{1}$ \\ ${ }^{1}$ Russian University of Transport RUT (MIIT), Institute of Economics and Finance, Department of \\ Economics and Transport Management, 9b9 Obrazcova Ulitsa, Room 1301, Moscow 127994
}

\begin{abstract}
Research background: Despite the sanctions pressure, consequences of the pandemic coronavirus infection COVID-19 and other non-economic factors, the study of the impact of globalization processes on the country's economy comes to the fore today, as Russia is one of the key elements of the world economic system in these difficult conditions. The dynamics of world commodity markets influence the internal economic processes of the country. The authors conclude that the processes of globalization through the influence of the world commodity markets have a significant impact on the capabilities of Russia's transport complex and require the development of its transport potential on the principles of economic growth.

Purpose of the article: Determination of the impact of globalization processes on the renewal of the transport potential of Russia on the basis of a comprehensive assessment of the economic situation.

Methods: To conduct the study, we used statistical reporting. Along with traditional research methods (analysis, synthesis, classification), additive models were used to form an index of transport market conditions, which allowed us to identify statistically significant determinants that allow us to determine the main directions of development of Russia's transport potential in the context of increasing globalization processes.

Findings \& Value added: The results show that the most significant trends in the development of Russia's transport potential are determined by globalization processes and require their consideration when developing measures to upgrade and modernize the country's transport infrastructure. The developed conceptual model for assessing the impact of world commodity markets in the context of globalization of economic processes on the development of the country's transport system contributes to the development of tools to increase the transportation of both transit and export-import cargo.
\end{abstract}

Keywords: Transport market conditions; world commodity market conditions; transport component; globalization, transport infrastructure.

JEL Classification: C55; E32; F01; F63; L91

\footnotetext{
${ }^{*}$ Corresponding author: podsorin@mail.ru
} 


\section{Introduction}

In the last two years, the economic downturn was caused by the spread of a new coronavirus infection COVID-19 and the widespread introduction of quarantine restrictions, which caused a significant reduction in supply and a compression of consumer and investment demand. In this regard, a sharp change in commodity markets caused a decline in trade between countries (by 8.5\% compared to the level of 2019). Changes in the structure of markets led to the disruption and subsequent transformation of global production chains. In the group of developed countries, GDP declined by $4.7 \%$ in 2020 (versus growth of $1.6 \%$ in 2019 ), and in the group of developing countries by $2.2 \%$ (growth of $3.6 \%$ in 2019).

The implementation by governments around the world to help people and businesses in the face of a new coronavirus infection COVID-19, the easing or removal of quarantine restrictions contributed to the improvement of macroeconomic indicators in 2021.

It should be noted that the development of the Russian economy in general corresponded to the world trends and was under the negative influence of COVID-19 with the decrease of the consumer and investment demand. An additional negative influence on the Russian economy in 2020 was exerted by low world prices for oil and other commodities of the Russian export.

The structure of the Russian economy allows it to overcome the crisis phenomena, as many large enterprises, which make up its core, were not subject to restrictions due to the peculiarities of their production process. At the same time, the shares of small and mediumsized businesses and the service sector, which were hit hardest by the crisis and the ban on activities, in Russia are significantly lower than in developed countries.

Among the factors that supported the Russian economy in such a difficult period are the implementation of the anti-crisis program of the Government of the Russian Federation, the relatively mild monetary policy of the Bank of Russia, the redistribution by the population of significant funds, not spent abroad due to closed borders, for domestic consumption, as well as the development of transport infrastructure that facilitates the movement of goods in the current circumstances.

In 2020, cargo turnover of transport in Russia decreased by $4.9 \%$ relative to 2019 , to $5,397.2$ billion $\mathrm{t}-\mathrm{km}$, including cargo turnover of pipeline transport decreased by $8 \%$, air transport by $3.7 \%$, inland waterway transport by $8.6 \%$, automobile transport by $1.3 \%$, and only sea transport increased by $16.2 \%$ (Rosstat, 2020). Freight turnover of railway transport decreased by $2.2 \%$. At the same time, the share of rail transport in the structure of freight turnover of the country's transport system increased to $47.2 \%$ (1.3 p.p. higher than in 2019). The share of rail transport excluding pipeline transport was $87 \%$ ( 0.1 p.p. lower than in 2019$)$ (Rosstat, 2020). Rail transport is a key infrastructural element of the Russian economy and the basis of the country's transport system.

The activity of railway transport is closely connected with the state of the Russian economy and industry (Tereshina et al., 2019). The state of the conjuncture of commodity markets, which form the main products for transportation, determines the qualitative and quantitative indicators of railway transport work, as well as production relations in the context of financial aspects between cargo-generating enterprises and transport companies (Tereshina et al., 2020).

In this regard, the study of the processes of globalization and integration of the world economy contributes to the identification of factors to improve the effectiveness of interaction of production enterprises and organizations with the transport complex, improve the efficiency of transport infrastructure, ensure the sustainability of the national economy, as well as accelerate the globalization and integration of production processes of transnational structures.

The difficulty of economic assessment of the impact of globalization processes on the development of the Russian economy lies in the lack of direct functional links between the 
considered parameters of the formation of results, as well as the high political volatility of decisions made in terms of interaction with the economies of other countries. At the same time, the differences in the development of transport infrastructure by region have a negative impact on the integration processes of the country and globalization as a whole. Thus, transport support of globalization processes in Russia requires elaboration of prospective directions of development.

\section{Methods}

Analysis of commodity market conditions allows to identify qualitative and quantitative aspects of future changes in the transport market. In the short term, significant qualitative changes in the transport market are not expected. This conclusion is based on the fact that railway transport currently has excess capacity (although there are bottlenecks in some directions), the nature of current main freight flows makes it impossible to reorient them to other modes of transport, changes in the market model in the sphere of freight transportation by railroad transport are not expected, consolidation and consolidation of market positions of key players will not affect market changes.

Figure 1 shows the dynamics of indices of industrial production in Russia, the total volume of freight transported and freight turnover on the railway transport (Rosstat, 2020).

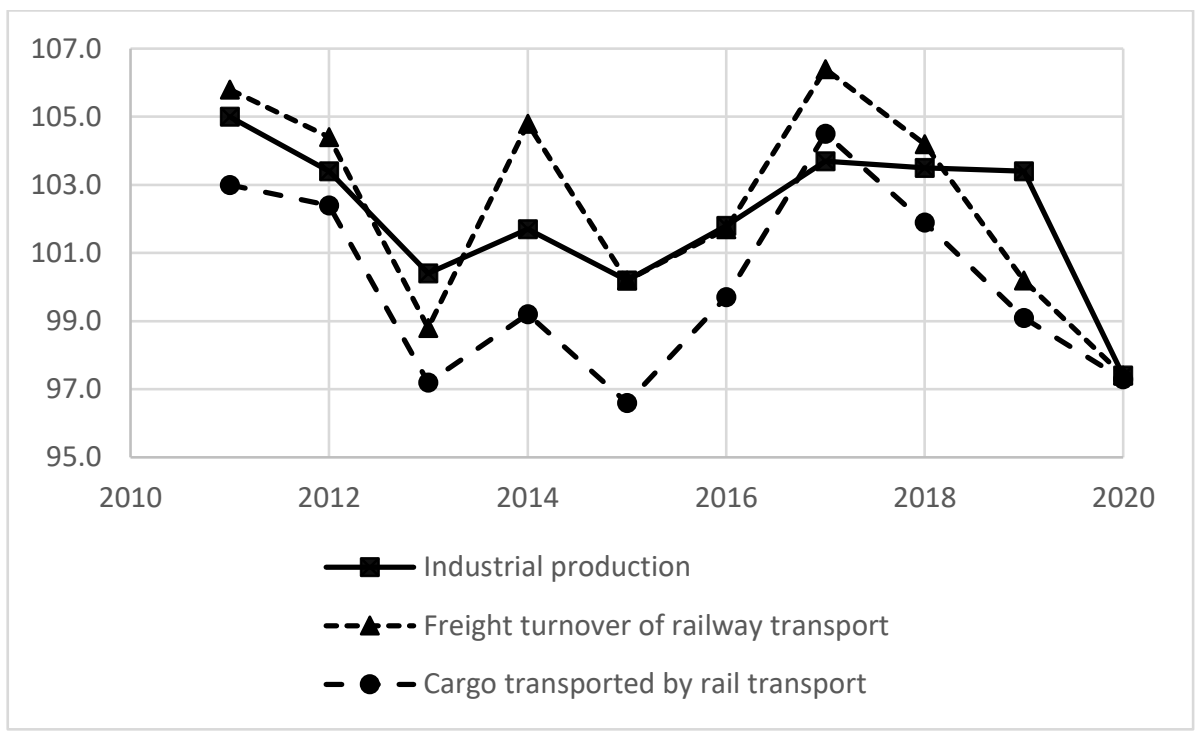

Figure 1. Dynamics of indices of industrial production in the Russian Federation, the total volume of transported cargo and freight turnover on the railway transport, \%.

Source: Podsorin and Ovsiannikova (2021)

Figure 1 shows that the curve of the index of industrial production is very close to the curves of the index of freight turnover and the index of cargo transported by rail. The correlation coefficient between the industrial output index and the index of cargo turnover, performed by the railway transport is equal to 0,94 , and the correlation coefficient between the industrial output index and the index of the volume of cargo transported by the railway transport is 0,93 . Thus, it can be stated that there is a strong correlation between the listed indicators.

Assessing the prospects of the dynamics of these indicators, it should be noted that freight turnover on the railway transport in january-july 2021 increased by $5 \%$ compared with the 
same period last year and amounted to 1520.4 billion tariff tkm. The loading for january-july 2021 amounted to 740.7 million tons, which is $4.5 \%$ more than for the same period last year. The maximum increase in loading by January-July 2020 occurred in the following cargoes: scrap of ferrous metals $(+29.9 \%)$; hard coal $(+9.9 \%)$; grain $(+9.7 \%)$; cement $(+7.8 \%)$ (JSCo «RZD», 2020).

A detailed model for assessing the transport market conjuncture index will make it possible to evaluate the dynamics of changes in transport work (Podsorin and Ovsyannikova, 2019). The index of the transport market conjuncture can be determined by the index of cargo turnover, taking into account the index of cargo carriage and the structure of cargo transportation by rail. The index of freight turnover by type of cargo reflects the index of commodity markets and, above all, the volume of production of the main mass cargoes. Table 1 shows freight turnover indices by main mass cargoes.

Table 2. Freight turnover indices by main mass cargoes.

\begin{tabular}{|c|c|c|c|c|}
\hline Name of cargo & $2014 / 2013$ & $2016 / 2015$ & $2018 / 2017$ & $2020 / 2019$ \\
\hline $\begin{array}{c}\text { Hard coal } \\
\text { Crude oil, including } \\
\text { gas condensate }\end{array}$ & 1,072 & 1,064 & 1,061 & 0,966 \\
\hline Construction cargo & 1,047 & 0,871 & 1,102 & 0,904 \\
\hline $\begin{array}{c}\text { Iron ore and } \\
\text { manganese ore }\end{array}$ & 0,872 & 1,216 & 0,961 & 0,989 \\
\hline $\begin{array}{c}\text { Mineral or chemical } \\
\text { fertilizers }\end{array}$ & 1,047 & 1,016 & 1,042 & 1,026 \\
\hline Grain & 1,036 & 1,026 & 1,008 & 1,008 \\
\hline Coke & 1,050 & 1,013 & 1,006 & 1,006 \\
\hline Other & 1,046 & 1,016 & 1,012 & 0,995 \\
\hline Total & 1,047 & 1,016 & 1,042 & 0,978 \\
\hline
\end{tabular}

Source: Podsorin and Ovsiannikova (2021)

As the data in table 1 show, the cargo turnover index in 2019 has the maximum value for the group Construction cargo and is 1.01. However, insignificant specific weight in the structure of cargo turnover does not affect indicators of the generalizing index of market conditions so much. At the same time the growth rate of cargo turnover for hard coal, which occupies more than $44.2 \%$ in the structure of shipments, is 0.966 .

\section{Results}

The majority of Russian coal is transported through Far Eastern ports, accounting for more than $55 \%$ of all Russian transshipments of this fuel. The throughput capacity of the Far East railroads is planned to increase to 190 million tons of cargo in all categories by 2024 . At the same time, according to the plans of coal companies, it is planned to increase deliveries in the direction of Far Eastern ports to more than 205 million tons (Analytics collection, 2020).

Transport support of globalization processes requires the implementation of large capitalintensive projects. Sources of financing of the Comprehensive Plan of modernization and expansion of the mainline infrastructure within the framework of the investment program of "Russian Railways" for 2020 is shown in figure 2 and table 2 (JSCo «RZD», 2020).

The key transport infrastructure development project is the development of the railway infrastructure of the Central Transport Hub (over 99.2 billion rubles). More than 69.7 billion rubles or $35.1 \%$ of the entire investment program of "Russian Railways" is allocated for the development of the railway infrastructure of the Eastern range of railroads. In (Shkurina et al., 2019) approaches to assessing the effectiveness of investment in infrastructure projects 
in transport based on the modeling of economic processes are proposed. This sources of investment are important in this case.

Table 2. Comprehensive plan for the modernization and expansion of trunk infrastructure by Federal projects within the framework of the investment program of "Russian Railways", 2020.

\begin{tabular}{|c|c|c|}
\hline $\begin{array}{c}\text { Key areas of the plan to modernize and expand the mainline } \\
\text { infrastructure }\end{array}$ & $\begin{array}{c}\text { Investment } \\
\text { volume, billion } \\
\text { rubles. }\end{array}$ & Share, \% \\
\hline $\begin{array}{c}\text { Development of the railway infrastructure of the eastern range of } \\
\text { the railroads }\end{array}$ & 69,7 & 35,1 \\
\hline $\begin{array}{c}\text { Development of railway approaches to the seaports of the Azov- } \\
\text { Black Sea basin }\end{array}$ & 16,0 & 8,1 \\
\hline $\begin{array}{c}\text { Development of railway approaches to the seaports of the North- } \\
\text { Western basin }\end{array}$ & 11,4 & 5,8 \\
\hline $\begin{array}{c}\text { Development of the railway infrastructure of the Central } \\
\text { Transport Hub }\end{array}$ & 99,2 & 50,0 \\
\hline Development of high-speed railways & 2,1 & 1,1 \\
\hline Total & 198,5 & 100 \\
\hline
\end{tabular}

Source: Podsorin and Ovsiannikova (2021)

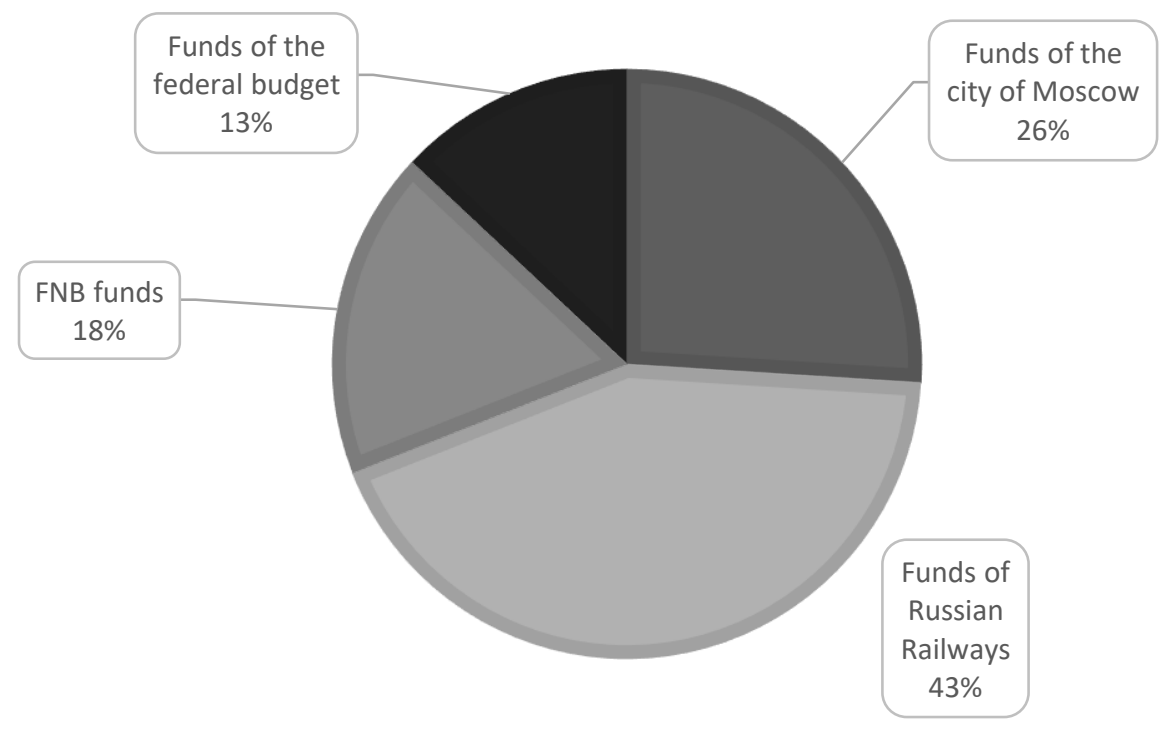

Figure 2. Sources of financing of the Comprehensive Plan for Modernization and Expansion of Trunk Infrastructure within the framework of the Russian Railways Investment Program for 2020.

Source: Podsorin and Ovsiannikova (2021)

The main source of financing of the Comprehensive Plan of Modernization and Expansion of Trunk Infrastructure within the framework of the investment program of "Russian Railways" for 2020 is the funds of "Russian Railways" more than $43 \%$. At the same time, federal budget funds account for about $13 \%$ and funds from Moscow.

The assessment of the transport market situation shows that the next years will require an increase in investments in the development of the transport infrastructure. Thus, transport market conjuncture index calculated on the basis of freight turnover index revealed the 
following tendencies: from 2015 till 2017 transport market index increased from 0.92 to 1.00 , and from 2017 till 2020 transport market conjuncture index decreased from 1.00 to 0.92.

The following conclusions and recommendations for improving transport support of globalization processes in Russia should be noted: the implementation of innovative investment projects, taking into account the environmental requirements of the global community, optimization of domestic production costs and incentives for insourcing, increasing spending on research and development and implementation of projects with breakthrough technologies. improvement of innovation infrastructure, involvement of private capital in the development of transport corridors to intensify traffic.

\section{Discussions}

The essence of globalization is the deep integration of economic relations and relations of countries and national markets in the direction of the integrity of the world economy, appears in the regional integration (EU, ASEAN, NAFTA) and in the determining role of international markets of raw materials, money, capital and currency (Rybakova et al., 2011).

Globalization contributes to the formation of new economic relations mediated by flows of goods, services, capital and information between countries. The activities of transnational corporations have become the main driver of globalization, shaping these relationships through vast networks of firms and their subsidiaries (Sigler et al., 2021).

The legal basis of globalization is the liberal national legislation of most countries of the world, allowing the free movement of capital, the application of international law, conditions, procedures for trade and financial transactions (Rybakova et al., 2011). The technological basis of globalization is the industries of information technology and engineering, which allow linking national financial and commodity markets with international ones. At the same time in modern conditions, there is a possibility of deeper integration of the economies of countries in connection with the development of transport and logistics technologies that allow optimizing the cost of material resources.

The transition from traditional technology with constant returns to modern methods with increasing returns in production not only expands the scale of production, but more importantly, it improves the quality of the product. This quality improvement consists mainly in a much higher level of transportability (Garcia and Pontes, 2021).

This (Forero et al., 2021) presents the main conclusions of the influence of rail transport on globalization processes. Among which we can highlight the following: railroads have increased urban population growth; railroads have increased specialization in agriculture; railroads have little effect on human capital and fertility. In this regard, the impact of transportation technology greatly contributes to the process of globalization.

Analyzing the transport support of globalization processes in world practice we can give an example of the development of the transport project of China - "One Belt and One Road". (One Belt, One Road / Belt and Road Initiative, BRI). The project covers 68 countries and regions, which together make up one third of the world economy and account for half of the world's population. This project has an impact on global commodity markets. Experts estimate that the annual volume of China's trade with the countries involved in the BRI project will be more than $\$ 2.5$ trillion. As a result of the BRI project implementation, cardinal changes in cargo traffic are predicted. At the same time, more and more high value-added and time-sensitive cargoes are being transported by rail.

In (Ezcurra and Del Villar, 2020) the connection between economic globalization and spatial inequality is investigated. The results of the study show a strong causal effect of the degree of economic integration with the rest of the world on spatial inequality. Thus spatial influence of globalization depends on a level of economic development (Ezcurra and Del Villar, 2020). 
The authors (Lukinskiy et al., 2018) in their study of changes in the logistics sector of transport services under the influence of globalization have developed a new approach based on the "Just in time" criterion. Improving the efficiency of supply chains in accordance with this criterion will take into account customer satisfaction.

Transport support of the population and economic processes in all countries is key in assessing the quality of life of citizens. Logistics companies create opportunities to form various logistics chains. However, in practice, such cooperation is not always feasible, despite the economic efficiency of technical solutions. For example, the transit potential of Russia is not fully utilized, despite the efficiency of cargo delivery by land relative to sea. This (Ferrell et al., 2020) offers an overview of existing research in the field of horizontal cooperation, especially highlighting the areas of logistics on demand, freight consolidation, capacity sharing, incentives, case studies, and quantitative analysis (Ferrell et al., 2020).

The authors (Rohacs J. And Rohacs D., 2020) estimate the impact on the development of the transport system of globalization. At the same time, the transport system has a significant impact on the environment. In this regard, the impact of transport support in the development of globalization should take into account the environmental consequences, which in modern conditions is especially relevant.

In continuing the impact of globalization on environmental consequences, we can refer to the study (Zaidi et al., 2019). The authors identify the dynamic links between globalization, financial development and carbon emissions in the Asia-Pacific Economic Cooperation (APEC) countries. The authors note that the processes of globalization and financial development reduce carbon emissions, but the economic growth caused by the processes of globalization increases them.

Thus, the transport support of globalization processes should be based on the doctrine of innovative development of society. At the same time it is necessary to highlight the global trends. For the balanced development and dynamic economic growth it is necessary to ensure the conditions of functioning of processes of acquisition, creation and diffusion of new knowledge. Such conditions will allow to develop the innovation system of the national economy, generate innovative changes in the economic system, which in turn will promote technological renewal and modernization of the production system in society (Kraft., 2015).

Innovative technologies act as a driver of long-term economic growth and increased global competitiveness. In (Varnavskii., 2020) various types of external and internal drivers of transport infrastructure development are considered in the context of the current stage of globalization. In (Voitolovsky et al., 2016) conditions for consolidation of technological leadership of the USA on the basis of innovations, eco-innovations, etc. are given. (figure 3).

As we can see, the U.S.A. addresses a wide range of issues and areas in which the U.S.A. has significant accomplishments are important.

The G7 countries in the context of globalization are also implementing innovative policies to achieve their goals. At the same time, despite their economic prosperity, they are experiencing difficulties in the field of ecology. In this regard, the processes of globalization have a huge impact on the economies of these countries. In (Ahmad et al., 2021) it is noted that globalization and eco-innovation reduce environmental impacts and it is recommended that $\mathrm{G} 7$ countries be more financially integrated, finance projects related to eco-innovation, promote sustainable urbanization and accelerate economic growth through a sustainable transformation of production and consumption processes. 
Formation of more favorable investment climate and competitive environment for innovative business activities;

Stimulation of reindustrialization and opposition to offshoring;

Securing the U.S.A. leadership in R\&D spending;

Focusing on breakthrough technologies of the next generations;

Increasing the efficiency of implementation of R\&D results;

Forming the "world's best" innovation infrastructure for the $21 \mathrm{st}$ century;

Orientation on human capital development and formation of the "world-class" labor force;

Winning a "fair market share" for the products of knowledgeintensive industries.

Figure 3. Conditions for the consolidation of U.S. technological leadership.

Source: Podsorin and Ovsiannikova (2021)

Thus, transport support can interfere with the global movement of goods and lead to economic and financial losses and environmental consequences both at the country level and at the level of the global economy.

\section{References}

1. Ahmad M., Jiang P., Murshed M., Shehzad K., Akram R., Cui L., \& Khan Z. (2021). Modelling the dynamic linkages between eco-innovation, urbanization, economic growth and ecological footprints for G7 countries: Does financial globalization matter? Sustainable Cities and Society, 70, 102881.

2. Ezcurra R., Del Villar A. (2020) Globalization and spatial inequality: Does economic integration affect regional disparities? Annals of Regional Science 67 (2), 335 - 358.

3. Ferrell, W., Ellis, K., Kaminsky, P., \& Rainwater, C. (2020). Horizontal collaboration: opportunities for improved logistics planning. International Journal of Production Research, 58(14), 4267-4284.

4. Forero A., Gallego F.A., González F., \& Tapia, M. (2021). Railroads, specialization, and population growth: evidence from the first globalization. Journal of Population Economics 34 (3), 1027 - 1072.

5. Investment in infrastructure: 2018, 2019, 2020. Analytics collection InfraONE Research. [Online]. Retrieved from: https://alpinabook.ru/catalog/book-investicii-20182020/

6. JSCo «RZD». Annual reports JSCo «RZD» [Online]. Retrieved from: www.rzd.ru

7. Kraft, Y. (2015). Globalization and development of the innovation system of the national economy. Innovation economy issues, 5 (3), 79-94. 
8. Lukinskiy, V., Lukinskiy, V., \& Merkuryev, Y. (2018). Modelling of transport operations in supply chains in obedience to "just-in-time" conception. Transport, 33(5), 1162-1172.

9. Pires A.J.G., Pontes J.P. (2021). (De)Industrialization, Technology and Transportation. Open Economies Review 32 (3), 527 - 538.

10. Podsorin V.A., \& Ovsyannikova E.N. (2019). Development of railway infrastructure in Russia taking into account commodity market conditions. Proceedings of the twelfth international conference Managing the development of large-scale mlsd systems'2019, 699-702.

11. Rohacs, J., \& Rohacs, D. (2020). Total impact evaluation of transportation systems. Transport, 35(2), 193-202.

12. Rosstat. Russia in figures. 2020: Stat. sat./ Rosstat [Online]. Retrieved from: https://rosstat.gov.ru/storage/mediabank/GOyirKPV/Rus_2020.pdf

13. Rosstat. Transport in Russia. 2020: Stat. sat./ Rosstat [Online]. Retrieved from: https://rosstat.gov.ru/storage/mediabank/UbzIvBZj/Transport_2020.pdf

14. Rybakova, F.F., Lyakina, A.N., \& Cisko, S. (2011) Globalization and infrastructure development. Nestor-History.

15. Shkurina, L., Maslova, M., Podsorin, V., \& Tereshina, N. (2019). Effective investment management with elements of simulation modelling. E3S Web of Conferences.

16. Sigler, T., Martinus, K., Iacopini, I., Derudder, B., \& Loginova, J. (2021) The structural architecture of international industry networks in the global economy. PLoS ONE. 16(8).

17. Tereshina N.P., Podsorin V.A., Ovsyannikova E.N. (2020). Development of transport infrastructure in the context of changing economic conditions. Journal of transport, 3 , 6-9.

18. Tereshina N.P., Podsorin V.A., Sokolov Yu.I. et al. (2019). Economics of railway transport. [Online]. Retrieved from: http://www.iprbookshop.ru/86683.html.

19. Varnavskii, V.G. (2020). Global transport \& logistics infrastructure. World Economy and International Relations, 64(1), 5-14.

20. Voitolovsky, F.G., Kirichenko, E.V., eds. (2016) USA: Opportunities and Limits of Economic and Political Leadership. Vol. 1, 240.

21. Zaidi, S.A.H., Zafar, M.W., Shahbaz, M., \& Hou, F. (2019). Dynamic linkages between globalization, financial development and carbon emissions: Evidence from Asia Pacific Economic Cooperation countries. Journal of Cleaner Production, 228, 533-543. 